\title{
Combination of Orthodontic Movement and Periodontal Therapy for Full Root Coverage in a Miller Class III Recession: A Case Report with 12 Years of Follow-up
}

\author{
Rafael Scaf de MOLON ${ }^{1}$ \\ Érica Dorigatti de AVILA ${ }^{2}$ \\ João Antonio Chaves de SOUZA ${ }^{1}$ \\ Andressa Vilas Boas NOGUEIRA ${ }^{1}$ \\ Carolina Chan CIRELLI ${ }^{3}$ \\ Joni Augusto CIRELLI ${ }^{1}$
}

\begin{abstract}
${ }^{1}$ Department of Diagnosis and Surgery; ${ }^{2}$ Department of Dental Materials and Prosthodontics; ${ }^{3}$ Department of Orthodontics, Araraquara Dental School, UNESP - Univ Estadual Paulista, Araraquara, SP, Brazil
\end{abstract}

\begin{abstract}
One of the main purposes of mucogingival therapy is to obtain full root coverage. Several treatment modalities have been developed, but few techniques can provide complete root coverage in a class III Miller recession. Thus, the aim of this case report is to present a successful clinical case of a Miller class III gingival recession in which complete root coverage was obtained by means of a multidisciplinary approach. A 17-year-old Caucasian female was referred for treatment of a gingival recession on the mandibular left central incisor. The following procedures were planned for root coverage in this case: free gingival graft, orthodontic movement by means of alignment and leveling and coronally advanced flap (CAF). The case has been followed up for 12 years and the patient presents no recession, no abnormal probing depth and no bleeding on probing, with a wide attached gingiva band. A compromised tooth with poor prognosis, which would be indicated for extraction, can be treated by orthodontic movement and periodontal therapy, with possibility of $100 \%$ root coverage in some class III recessions.
\end{abstract}

Key Words: gingival recession, connective tissue graft, Orthodontics, multidisciplinary approach.

\section{INTRODUCTION}

Gingival recession is defined as the displacement of the gingival margin apical to the cementoenamel junction (CEJ) with exposure of the root surface to the oral environment (1) and may involve one or more tooth surfaces (2). In 1985, Miller (3) presented a classification of recessions and, according to this author, root coverage is more predictable and more successful with class I and II defects. However, only partial coverage can be expected with class III defects whereas in class IV no coverage can be done.

The etiologic factors for gingival recession are considered multifactorial, and the predisposing factors act simultaneously with the triggering factors (4). The predisposing factors associated with this condition include: labial orthodontic tooth movement (5), bone dehiscence and fenestration (6), thin gingival biotype (7), malposition of the teeth (8) and others. The triggering factors are mainly associated with trauma resulting from inadequate or excessive toothbrushing and/or inflammatory reactions in the gingiva due to plaque and calculus accumulation (9).

Another possible etiological factor for gingival recession is the orthodontic movement of the teeth, specially the movement of teeth to positions outside the buccal or lingual alveolar plate. If the alveolar bone is thin and the teeth are moved buccally, a significant reduction in the bone height and apical migration of the marginal gingiva may occur (10). Thus, malpositioning of teeth 
is associated to the development of gingival recession. On the other hand, some orthodontic movements such as body movement can improve gingival recession (11). However, for the orthodontic movement to contribute to reduction of gingival recession, it is important to have sufficient keratinized gingiva. According to Wennstrom et al. (12), the amount of keratinized tissue influences the outcome of root coverage; thick tissues and large amounts of keratinized tissue have a favorable prognosis.

The primary goal of free gingival graft is to increase the band of attached gingiva and stop the progressive gingival recession. However, in cases of narrow recession $(<3 \mathrm{~mm})$, some root coverage can be achieved with this treatment because most part of the graft remains viable on the receptor site (13).

This paper presents a successful clinical case of a Miller class III gingival recession in which complete root coverage was achieved by means of a multidisciplinary approach involving free gingival graft, orthodontic movement followed by coronal advanced flap (CAF), allowing to achieve better aesthetic results. To the best of our knowledge, this case of complete root coverage of a class III gingival recession after periodontal surgery and orthodontic movement is the first report in the dental literature.

\section{CASE REPORT}

A 17-year-old Caucasian female patient came to the Department of Periodontology of Araraquara Dental School complaining of dental sensitivity and aesthetic problems on the mandibular left central incisor. Her medical history was noncontributory, with healthy systemic conditions, no known drug allergies and denied smoking and use of alcohol. The patient had never been treated for periodontal disease and no orthodontic treatment had been performed. The intense sensitivity associated with root exposure was the reason for her visit to the dentist.

A periodontal examination was performed including assessment of probing depth (PD), clinical attachment levels (CAL), full-mouth bleeding and plaque scores. Intraoral examination revealed an intensive gingival inflammatory process on the mandibular left central incisor, with a $9 \mathrm{~mm}$ gingival recession, bacterial plaque, bleeding on probing (BOP), absence of sufficient keratinized gingiva and no abnormal PD (Fig. 1A). The periapical radiographs showed interproximal bone resorption in the mandibular left central incisor (Fig. 1B), with a $2 \mathrm{~mm}$ loss of alveolar bone crest. The occlusal examination showed a protruded mandibular left central incisor. Based on the collected data, a diagnosis of Miller class III gingival recession with anterior dental crowding was made.

The orthodontic treatment was planned for the mandibular central incisor and an autogenous free gingival graft was recommended for increasing the width of attached gingiva, before the planned orthodontic procedure. The initial treatment involved oral hygiene instructions and supragingival and subgingival scaling followed by root planning. After the periodontal treatment, the patient exhibited good plaque control and clinically healthy gingival tissues.

The surgical procedure was made by creation of a partial-thickness flap according to Miller's techniques. The gingival tissue graft was obtained from the palatal side. The autogenous graft was sutured on the receptor site with interrupted and compressive sutures (4-0 silk
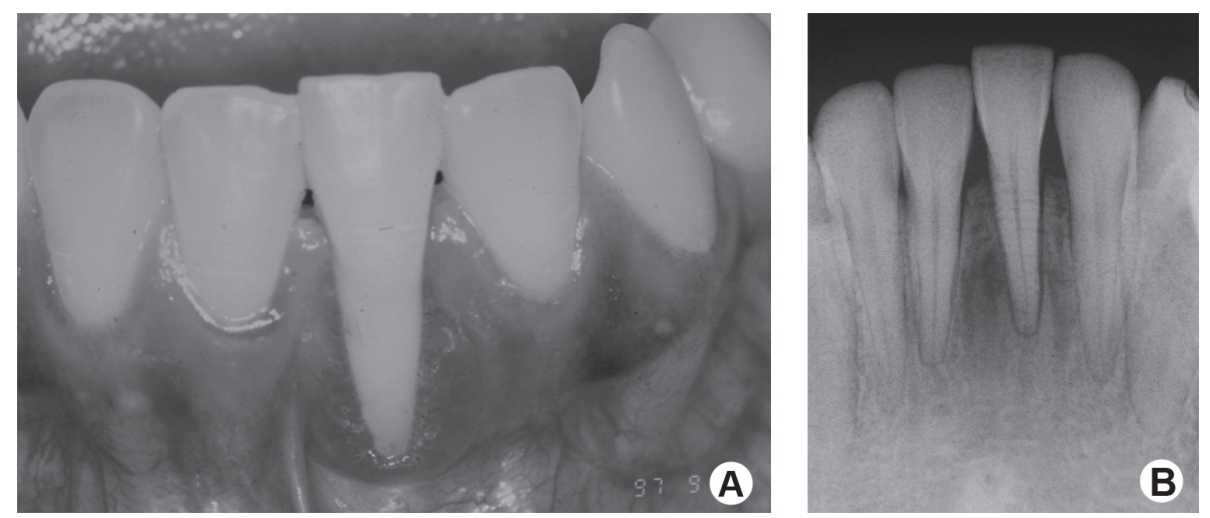

Figure 1. Clinical image showing $9 \mathrm{~mm}$ of gingival recession class III Miller involving the permanent mandibular left central incisor (A) and periapical radiograph showing bone resorption in the interproximal area of the same tooth (B). 
suture) for an adequate graft adaptation (Fig. 2). A non-eugenol periodontal dressing was applied to the donor and recipient sites. Patient received post-surgical instructions. Sutures were removed 1 week after the surgical procedure. Two months after surgery, a large increase of keratinized gingiva width was observed around the central incisor and root coverage was achieved on the buccal root, but a $6 \mathrm{~mm}$ recession was still present (Fig. 3).

The patient was followed during 1 year and 9 months for postoperative care and was referred to an orthodontist for further treatment and management of the malposition of the mandibular left central incisor (Fig. 4A). Orthodontic treatment was started to create an acceptable tooth position by means of alignment and leveling. Brackets were placed on the mandibular teeth, from canine to canine. The bodily movement started according to the clinical need to realign the tooth, with sectional wires and light forces. After 4 months of active orthodontic treatment, acceptable results were achieved and the buccal root was resolved (Fig. 4B).

Following the orthodontic treatment, the patient was seen biweekly during the first 4 months.

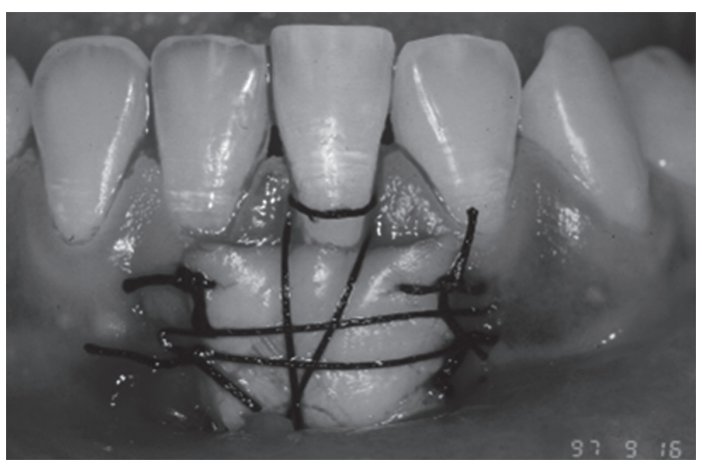

Figure 2. Suture of the autogenous graft on the receptor site.
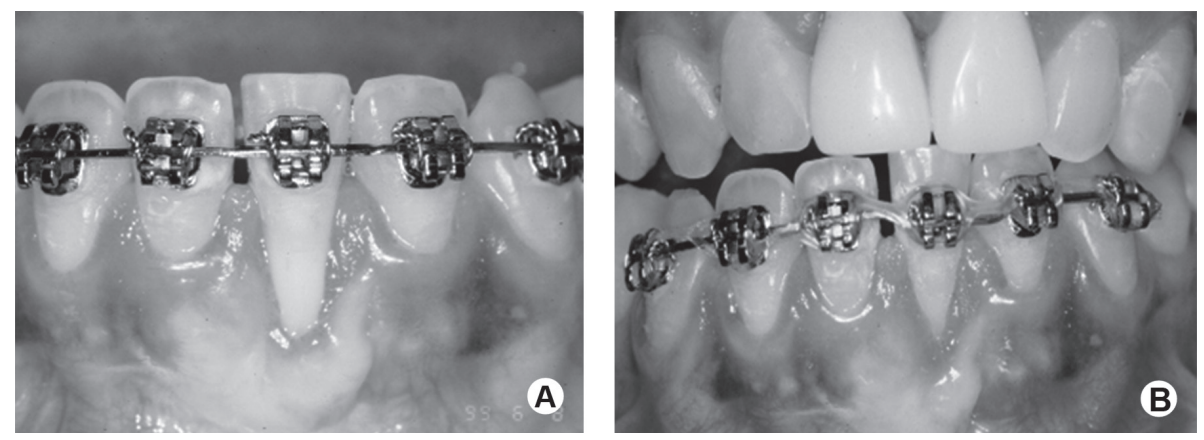

Figure 4. Clinical images 1 year and 9 months postoperatively (A) and 4 months after active orthodontic treatment (B).
Maintenance visits consisted of reinforcement of oral hygiene instructions and professional prophylaxis. During this period, the orthodontic treatment promoted coronal displacement of the gingival margin covering 4 $\mathrm{mm}$ the denuded root of the central incisor. Despite this coronal displacement of the margin, a gingival recession was still there. For this reason a CAF was planned for complete coverage of this class III recession.

CAF was performed with 2 vertical incisions on mesial and distal aspects of the recession. Papillae were not included on flap. The vertical incision extended from the cementoenamel junction (CEJ) to the alveolar mucosa. A partial-thickness trapezoidal flap was achieved and allowed the free coronal positioning of the flap. The flap was positioned $1 \mathrm{~mm}$ coronal to the CEJ and maintained in place with individual 4.0 silk sutures (Fig. 5). Sutures were removed 7 days after surgery. The patient was instructed to maintain regular oral home care by gentle brushing the teeth with extra soft-bristle tooth brush and topical applications of $0.12 \%$ chlorhexidine gluconate.

At the end of this treatment the patient showed absence of recession, no abnormal PD, no BOP and no

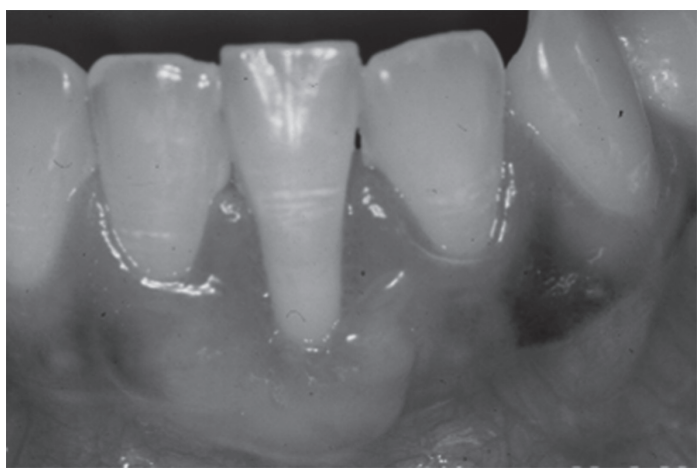

Figure 3. Clinical image 2 months postoperatively. 
plaque scores. The gingival color, texture and contour appeared similar to the adjacent soft tissues of the teeth. These characteristics were observed postoperatively after the first year (Fig. 6A). Past the first year, the patient did not return for the subsequent evaluation and follow-up sessions.

After 12 years, the patient sought the dental school clinic and reported that she did not receive any dental care during this period. However, the patient did not complain about the treatment of the mandibular left central incisor, she was rather pleased with the absence of sensitivity and good aesthetics. Therefore, clinical success was achieved in this case involving a multidisciplinary treatment of a class III gingival recession even after 12 years (Fig. 6B).

\section{DISCUSSION}

The treatment of buccal gingival recession for aesthetics or root sensitivity is a common demand of patients with high standards of oral hygiene (1). Several mucogingival procedures have been tested to move

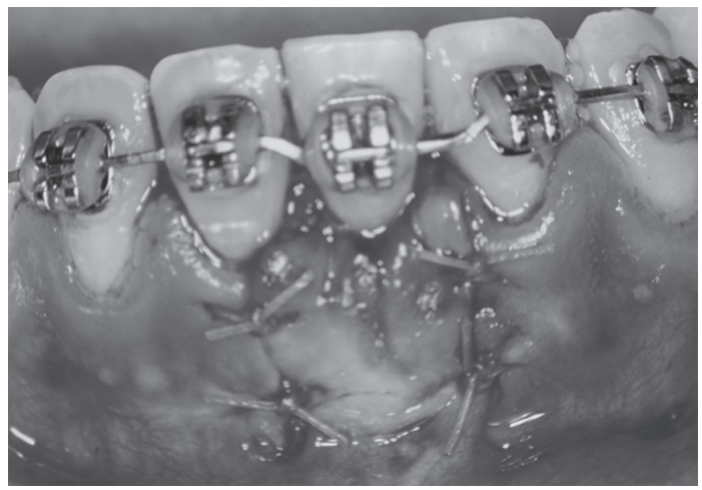

Figure 5. Coronal advanced flap for treatment of the gingival recession. the gingival margin coronally. This paper describes a combined surgical and orthodontic approach for the treatment of gingival recession. The localized recession may be a consequence of the prominent position of the mandibular anterior teeth, presence of bone dehiscence and thin gingival tissue. Many authors believe that tooth position has an influence on root coverage (6-8). In the present case, it was considered necessary to enhance the gingival thickness before other procedures for root covering could be done.

Among the different types of procedures, autogenous free gingival graft is a good options to increase the width of attached gingiva and then start the orthodontic treatment for creating an acceptable tooth position by means of alignment and leveling (11). Huang et al. (14) concluded that the initial gingival thickness $(\geq 1.2 \pm 0.3 \mathrm{~mm})$ is the most decisive factor regarding the accomplishment of complete root coverage. In this case, the patient has a narrow dental biotype and thin gingiva, which is more susceptible to recession of the soft tissue margin than patients with wide dental biotype and thick gingiva. The increased keratinized attached gingiva appears to provide continued stability, decreased potential for future clinical attachment loss, increased resistance to external injury and contributes to the stabilization of the gingival margin (10,15-17). Scientific evidences indicate that wider keratinized gingiva band is associated with a better probability of complete root coverage with a coronal advanced flap (18).

Some factors affect the successful results of full root coverage in a Miller class III recession: interproximal soft tissue integrity, width of the recession, interproximal bone resorption, use of grafts thicker than $2 \mathrm{~mm}$ (19), patient dental hygiene and tooth position (20). According to Esteibar et al. (19), class III recessions can only be partially covered. The authors assessed the factors involved with the achievement of
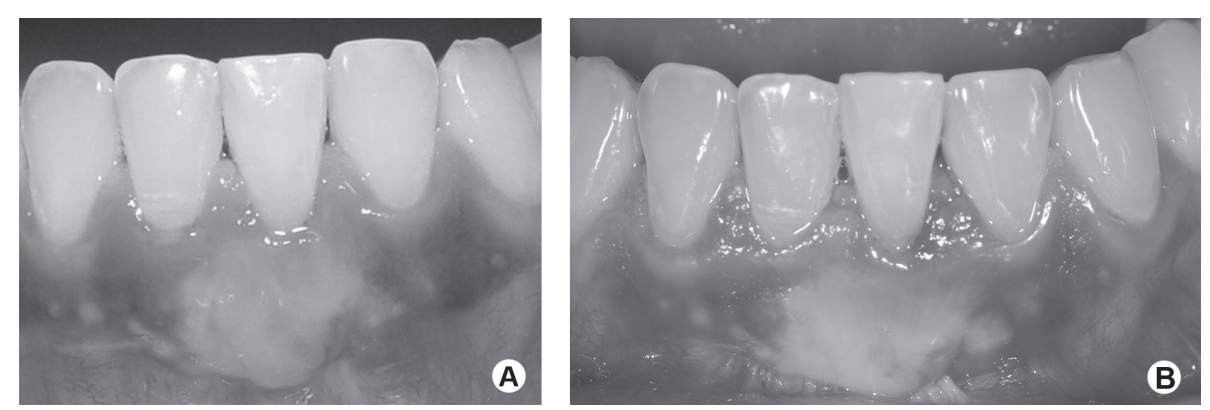

Figure 6. Clinical images 1 year postoperatively (A) and 12 years postoperatively (B). 
a complete root coverage in class III recessions using the following procedures: free grafts, a subepithelial connective tissue graft and connective tissue double pedicle graft and obtained only $47 \%$ of complete root coverage. However, the authors did not consider the tooth position, did not speculate if the tooth position could have interfered in the final results and did not perform any orthodontic procedures in combination with the surgical techniques. In the present case, tooth position interfered with the coronal cell migration of the free gingival graft. The gingival aesthetics was completed only after the orthodontic treatment. In summary, for a well-designed clinical trial, a careful observation of the long-term clinical healing process of autogenous gingival grafts is required to identify the factors that could play a significant role in this interesting clinical finding.

In this case, the orthodontic treatment alone was not sufficient to achieve complete root coverage. After 4 months, a significant coronal displacement of the gingival margin occurred, covering $4 \mathrm{~mm}$ of the denuded root of the central incisor, but root denudation persisted. Subsequent to autogenous free gingival graft and orthodontic treatment, CAF was planned to cover the remaining $5 \mathrm{~mm}$ of the recession and, consequently, improve the aesthetic parameters (21). According to De Sanctis et al. (22), CAF is the first choice when there is adequate keratinized tissue apical to the exposure of the root in patients with high aesthetic expectations. However, other authors have shown that the CAF may be used as root coverage procedure for the treatment of localized recession, providing excellent aesthetic results $(23,24)$. Pini Prato et al. (25) have stated that the position of the gingival margin interferes in the final results. Those authors showed that when the flap is positioned 1-2 mm coronal to the cementoenamel junction, occurs a complete root coverage. In the present case report, the flap was positioned $1 \mathrm{~mm}$ coronal to the CEJ and the final result was consistent with the scientific literature.

According to Cortellini et al. (17), there is no information as to whether tooth position (buccal or lingual) might influence the outcome of surgical mucogingival procedures. Esteibar et al. (19), on the other hand, stated that it seems likely that the attainment of complete root coverage in cases traditionally classified as Miller class III and considered less severe would not occur by chance, but rather be a response to some preoperative clinical variables and intraoperative measures. In this study, the association of procedures can be suggested as a safe and efficacious approach to the treatment of a class III gingival recession. In the presence of thin gingival tissue, the increased keratinized gingiva width created with gingival autograft improves the esthetic results associated with orthodontic movement and periodontal surgery. The surgical procedure yielded favorable esthetic outcomes and complete patient satisfaction. Successful treatment depends on the multidisciplinary approach to achieve better aesthetic results.

In conclusion, this case report illustrates a positive outcome in the treatment of a class III gingival recession. From a clinical point of view, the free gingival graft allowed increasing the width of keratinized gingiva band and the orthodontic treatment resulted in alveolar bone gain and, consequently, in reduction of the gingival recession. Moreover, $\mathrm{CAF}$ allowed achieving complete root coverage and improving aesthetics.

\section{RESUMO}

Um dos principais objetivos da terapia mucogengival é atingir a cobertura completa da raiz. Diversas modalidades de tratamento têm sido desenvolvidas, mas poucas técnicas podem obter a cobertura total da raiz em uma recessão gengival classe III de Miller. Assim, o objetivo deste relato é apresentar um caso de sucesso clínico de uma recessão gengival classe III de Miller na qual foi obtida a cobertura completa da raiz por meio de uma abordagem multidisciplinar. Uma jovem de 17 anos sexo feminino, leucoderma, foi encaminhada para tratamento de uma recessão gengival no incisivo central inferior esquerdo. Para a cobertura radicular foi planejado: enxerto gengival livre, movimento ortodôntico por meio de alinhamento e nivelamento e retalho reposicionado coronariamente (CAF). Este caso tem sido acompanhado por 12 anos e o paciente apresenta ausência de recessão, sem profundidade de sondagem anormal e sem sangramento à sondagem com ampla faixa de gengiva inserida. Dentes comprometidos e com mau prognóstico, que seriam extraídos em muitos casos, podem ser tratados por meio de movimento ortodôntico e terapia periodontal. 100\% de cobertura da raiz é possível e pode ser conseguida em alguns casos de recessão gengival classe III.

\section{REFERENCES}

1. The American Academy of Periodontology. Glossary of Periodontal Terms, 4th edition. Chicago: American Academy of Periodontology; 2001.

2. Zucchelli G, Mele M, Stefanini M, Mazzotti C, Mounssif I, Marzadori M, et al.. Predetermination of root coverage. J Periodontol 2010;81:1019-1026.

3. Miller PD Jr. A classification of marginal tissue recession. Int $J$ Periodontics Restorative Dent 1985;5:8-13.

4. Wennstrom J. Mucogingival therapy. Ann Periodontol 1996;1:671701.

5. Löst $\mathrm{O}$. Depth of alveolar bone dehiscence in relation to gingival recessions. J Clin Periodontol 1984;11:583-589. 
6. Kôliestal C, Uhlin S. Buccal attachment loss in Swedish adolescents. J Clin Periodontol 1992;19:485-491.

7. Steiner GG, Pearson JK, Ainamo J. Changes of the marginal periodontium as a result of labial tooth movement in monkeys. $\mathrm{J}$ Periodontol 1981;52:314-320.

8. Müller HR, Eger T. Gingival phenotypes in young male adults. J Clin Periodontol 1997;24:65-71.

9. Joshipura KJ, Kent RK, DePaola PF. Gingival recession: intraoral distribution and associated factors. J Periodontol 1994;65:864871.

10. Bonacci FJ. Hard and soft tissue augmentation in a postorthodontic patient: a case report. Int J Periodontics Restorative Dent 2011;31:19-27.

11. Corrente G, Abundo R, Re S, Cardaropoli D, Cardaropoli G. Orthodontic movement into infrabony defects in patients with advanced periodontal disease: a clinical and radiological study. J Periodontol 2003;74:1104-1109.

12. Wennstrom JL, Zucchelli G. Increased gingival dimensions. A significant factor for successful outcome of root coverage procedures? A 2-year prospective clinical study. J Clin Periodontol 1996;23:770-777.

13. Sullivan HC, Atkins JH. The role of free gingival grafts in periodontal therapy. Dent Clin North Am 1969;13:133-148.

14. Huang LH, Neiva RE, Wang HL. Factors affecting the outcomes of coronally advanced flap root coverage procedure. J Periodontol 2005;76:1729-1734.

15. Hassell TM. Tissues and cells of the periodontium. Periodontol 2000 1993;3:9-38

16. Baldi C, Pini Prato GP, Pagliaro U, Nieri M, Saletta D, Muzzi L, et al.. Coronally advanced flap procedure for root coverage. Is flap thickness a relevant predictor to achieve root coverage? A 19-case series. J Periodontol 1999;70:1077-1084.

17. Cortellini P, Pini Prato G. Coronally advanced flap and combination therapy for root coverage. Clinical strategies based on scientific evidence and clinical experience. Periodontol 2000 2012;59:158-184.
18. Allen EP, Miller PD. Coronal positioning of existing gingiva: short term results in the treatment of shallow marginal tissue recession. J Periodontol 1989:60:316-319.

19. Esteibar JR, Zorzano LA, Cundín EE, Blanco JDM, Medina JORG. Complete root coverage of Miller Class III recessions. Int J Periodontics Restorative Dent 2011;31:e1-7.

20. Richman C. Is gingival recession a consequence of an orthodontic tooth size and/or tooth position discrepancy? "A paradigm shift". Compend Contin Educ Dent 2011;32:62-69.

21. Zucchelli G, Mele M, Mazzotti C, Marzadori M, Montebugnoli L, De Sanctis M. Coronally advanced flap with and without vertical releasing incisions for the treatment of multiple gingival recessions: a comparative controlled randomized clinical trial. J Periodontol 2009;80:1083-1094.

22. De Sanctis M, Zucchelli G. Coronally advanced flap: a modified surgical approach for isolated recession-type defects: Three-year results. J Clin Periodontol 2007;34:262-268

23. Nieri M, Rotundo R, Franceschi D, Cairo F, Cortellini P, Pini Prato GP. Factors affecting the outcome of the coronally advanced flap procedure: a Bayesian network analysis. J Periodontol 2009;80:405-410.

24. Chambrone L, Sukekava F, Araújo MJ, Pustiglione FE, Chambrone LA, Lima LA. Root-coverage procedures for the treatment of localized recession-type defects: a cochrane systematic review. J Periodontol 2010;81:452-478.

25. Pini Prato GP, Baldi C, Nieri M, Franceschi D, Cortellini P, Clauser C, et al.. Coronally advanced flap: the post-surgical position of the gingival margin is an important factor for achieving complete root coverage. J Periodontol 2005;76:713-722.

Received June 1, 2012 Accepted December 5, 2012 